\title{
Previous Kondratieff Cycles: Many Positive and Some Negative Effects, and a Hopeful Outlook in the Short Kondratieff Cycle
}

\author{
Josef Gruber HC
}

Honorary President of the German Association for Space Energy Association (DVR), An der Herberge 7, D-58119 Hagen, Germany

"Corresponding author: Gruber HCJ, Honorary President of the German Association for Space Energy Association (DVR), Ander Herberge 7, D-58119 Hagen, Germany, Tel: (0049) - (0) 23 34-32 13; Fax: (0049) -23 34-4 37 81; E-mail: josef.gruber@fernuni-hagen.de

Received Date: April 10, 2015; Accepted Date: April 13, 2015; Published Date: April 20, 2015

Copyright: $\odot 2015$ Gruber HCJ. This is an open-access article distributed under the terms of the Creative Commons Attribution License, which permits unrestricted use, distribution, and reproduction in any medium, provided the original author and source are credited.

\section{Introduction}

Each Kondratieff cycle is characterized by a new technique (or more new techniques), the economy, society, life imprinted on some (or more) for decades, the positive effects of a new technique to characterize the new Kondratieff cycle. In the listed Kondratieff cycles are the clothing, mass transport, mass consumption, personal mobility, information / communication and holistic health. The theory of Kondratieff cycles is based on the theory of long waves. The particular strength of the long wave theory is that it enables a holistic approach to the problems of the time. Basically, it is the only scientific theory convincingly can be explained by the interaction between technological, economic, social and intellectual developments and thereby solid short-term and long-term forecasts are possible. Below I will give to each of the listed Kondratieff cycles some information about the main positive effects that characterize this cycle, so to speak. The focus then lies also in negative (adverse) effects that help shape this cycle. These designs are intended to encourage as many readers to make a gentle current Kondratieff cycle still possible beneficial to all people and the whole of nature (and not just individual groups, corporations, etc. to provide huge benefits at the expense of people and nature). Finally, I will on another, brand new and in my opinion starting soon Kondratiev cycle point 7 Kozy thanks Raumenergietechnology (RET).

\section{The Previous Kondratieff Cycles (Kozy)}

\section{Kondratieff cycle: start 1780}

\section{Steam engine, textile industry- A main effect: Clothing}

This is the first Kondratieff cycle in the book of Nefiodow. In Focus die, die steam engine and textile industry. The steam engine (As you probably read in each lexicon, here for example in Meyer's Big Taschenlexikon can) A heat engine in which standing under pressure steam in a cylinder piston A moves. The pressure energy is converted into mechanical energy BY relaxation. The steam Does either only on one side of the piston A (single-acting steam engine), or alternately on both sides (double-acting steam engine). The piston, die A unit outward sealed piston rod and crosshead making. On the cross head sliding in one linear guide is dying with a connecting rod end movably mounted, its other end includes die crankshaft on the flywheel. Use the connecting rod going to die hindrance and-forth movement of the piston in die rotary motion of the flywheel implemented. The flywheel compensates deviations in the torque and drives the piston about the dead center. The release of steam or other authority access to the a side of the piston is rarely controlled usually with sliders with valves (gate valve or valve control). The slide (oyster or spool) if by a moving eccentric on the crankshaft, valves die by cam. Steam engines are mostly with superheated steam plants (hot steam engine). After the pressure head at the outlet back pressure, exhaust and condensation machinery Become a distinction. Twin or triple machines have two or three cylinders with the same displacement, is relaxed by the boiler pressure on the exhaust pressure in the steam those. In composite or compound steam engines steam is successively relaxed in several (usually two or three) cylinders with different capacity. The first directacting steam engine Baute James Watt 1765 1782-1784, the first double-acting low pressure machine with rotary motion. 1798 Baute R. Trevithick 1801 O. Evans die high pressure steam engine, 1892 Wilhelm Schmidt The first hot steam engine. Because of their relative performance in complex construction and the low efficiency was dying steam engine steam turbines by displaced. A second pillar of the 1st Kondratieff cycle that has benefited from the steam engine very much, the textile industry, the textile industry: plants processing textile raw materials. The textile industry is traditionally labor-intensive. Large structural changes took place after the Second World War. Since then, large production capacities of the clothing industry were relocated from the western industrialized countries to low -wage countries, especially to Asia There, many people are still working to extremely low wages, living in inhumane conditions. This is a condition that can be regarded as a negative effect of 1 Kozy, which actually does not have exists.

\section{Ukrainian scientists: mobile phone radiation destroys cells}

"But how our body responds to mobile phone radiation? This topic is concerned, the Kiev Institute of Experimental Pathology, Oncology and Radiobiology". In the journal "Oxidants and Antioxidants in Medical Science" from 29.03.2014, the research group shows a clear link between cell phone radiation and on degradation processes in cells. The scientists, led by Igor Yakymenko have it analyzed 80 studies. In 76 of these studies the mechanism of damage could be detected. This scientific proof was again started that any radio radiation, also well below the regulatory limits, which damages the cells in living organisms and thus life-threatening diseases such as Causes cancer. Therefore: Do this finding by and find out comprehensively ..."

Weather modification and prevention of natural disasters, this is a problem area that actually requires a whole book. But here must satisfy some clues. There is information that is in claiming that the weather is "artificial" influenced many years, for example we can extreme drought and drought, extreme rainfall can produce (e.g. torrential rain with floods). Earthquakes are "producible". Occurring in this context designations are mainly HAARP, Chemtrails (chemically generated flight lines). The health of humans and animals is influenced. 
Citation: Gruber HCJ (2015) Previous Kondratieff Cycles: Many Positive and Some Negative Effects, and a Hopeful Outlook in the Short Kondratieff Cycle. Fluid Mech Open Acc 2: 115. doi:10.4172/2090-8369.1000115

Page 2 of 2

\section{Kondratieff Cycle: Beginning about 2000 - 2005}

\section{Biotechnology, psychosocial health-main effect: Holistic health}

In the preface to his book "The sixth Kondratieff" writes Nefiodow: The sixth Kondratieff cycle has begun parallel to the outlet of the fifth and its carrier will be the one area of the company that owns the largest untapped productivity and growth reserves for a self-sustaining recovery. Health market: In the present sixth edition of this book it states: There are new chapters 7 to 10 , which directly address the issue of information medicine for the first time systematically. With the unfolding of the sixth Kondratieff is becoming increasingly clear that a completely new approach to illness and health will be opened on the concept of information. Nefiodow explained in his book on pages 263-266 relatively short and in several chapters of the book details how he sees and explains the 6th Kondratieff cycle. Nefiodow provides information technology that has significantly influenced the 5th Kondratieff cycle, the focus of the sixth Kondratieff cycle. Information technology is also indispensable in the development of the other candidates of the sixth Kondratieff cycle: environmental protection, renewable energies, psyschosoziale information and health. In the cross-linking between the fifth and sixth Kondratieff cycle through the information technology put an enormous innovation and productivity potential. In the 2nd chapter of his book (p 23-47) Leo A. Nefiodow examines the major new markets of the 21 st century for their chance to solve economic problems, so to speak, to act as a locomotive for the sixth Kondratieff cycle. The individual candidates "for the sixth
Kondratieff cycle are discussed in other chapters of Nefiodow book. A kind of summary I found on page 64 under the heading "The common denominator of the sixth Kondratieff". "Considering all candidates who were called at the beginning of the second chapter as possible triggers and winner of the sixth Kondratieff - Information Market, environmental protection, biotechnology and health - and one asks if they have something like a common denominator, it is noticeable that their content is aligned wholly or mainly on health and disease. Environmental conservation, as already mentioned, mainly out of concern for our health instead. The most important applications of biotechnology are in the healthcare market, and also the information market has an important role to play in future health care. In the sixth Kondratieff the area of information market will be developed, with which the global entropy under can take control: the area of interpersonal information flows, information flows between people and the environment". This allows the leading sector, who will be the sixth Kondratieff, clearly: health in a holistic sense - physically, emotionally, spiritually, environmentally and socially. The new value chain, the power of new products, processes, services and technologies that will support the next long cycle, from the fields of information, the environment (including regenerative energies), biotechnology, the conventional disease sector and the emerging healthcare markets exist. "Contaminated sites (eg from nuclear energy use) will be eliminated by "new" transmutation process probably locally (ie without Castor transports) and create new materials. RE utilization widespread will also allow poor developing countries, sustainable solutions to their energy problems." 